\title{
Feeding behavior of the infaunal bivalve Tagelus dombeii (Lamarck, 1818). Suspension vs. deposit feeding
}

\author{
Conducta alimentaria del bivalvo infaunal Tagelus dombeii (Lamarck, 1818). Alimentación \\ suspensívora $v s$. detritívora
}

\author{
Jorge M. Navarro ${ }^{1 *}$, Elena Clasing ${ }^{1}$, Marco Lardies ${ }^{2}$ and Robert A. Stead ${ }^{3}$ \\ ${ }^{1}$ Instituto de Biología Marina 'Dr. Jürgen Winter'. Universidad Austral de Chile, Casilla 567, Valdivia, Chile \\ ${ }^{2}$ Departamento de Ciencias Básicas - CIENCIA-UST, Universidad Santo Tomás, Ejército 146, Santiago, Chile \\ ${ }^{3}$ Centro de Investigación 'i-mar', Universidad de Los Lagos, Casilla 557, Puerto Montt, Chile
}

jnavarro@uach.cl

Resumen.- El comportamiento alimentario de dos poblaciones del bivalvo Tagelus dombeii (Lamarck, 1818) fue estudiado mediante experimentos de laboratorio, con el objetivo de confirmar una posible estrategia dual de alimentación (suspensívora/detritívora). Individuos provenientes de la población intermareal de Coihuín (cerca de Puerto Montt, Chile) así como aquellos del submareal de Corral mostraron una conducta de alimentación por suspensión cuando estuvieron sumergidos, con una ausencia total de alimentación de depósito y con los sifones siempre abiertos a nivel de la superficie del sedimento. Estas observaciones fueron confirmadas por altas tasas de aclaramiento mostradas por ambas poblaciones de $T$. dombeii, similar a las descritas para bivalvos suspensívoros obligados. Resultados diferentes fueron obtenidos durante la emersión, cuando los individuos de $T$. dombeii de ambas poblaciones desplegaron sus sifones sobre el sedimento (3-5 $\mathrm{cm})$, comportándose como alimentadores de depósito. La alimentación de depósito fue observada hasta en el $80 \%$ de los individuos. Este estudio permite concluir que T. dombeii es principalmente un organismo con alimentación por suspensión, un hecho que podría estar relacionado con el tipo de sedimento disponible en el hábitat de las dos poblaciones estudiadas, que está compuesto principalmente por la fracción de arena ( $>92 \%)$. El período de crecimiento de esta especie coincide con los períodos de aumento de la oferta de alimento en su medio ambiente. Este hecho sugiere que T. dombeii estaría compitiendo por la oferta de alimento con la comunidad de bivalvos suspensívoros obligados en estos hábitats.

Palabras clave: Bivalvo, planicie mareal

\section{Introduction}

The tidal flats of southern Chile are characterised by the presence of numerous species of bivalve molluscs, many of which are of commercial importance (Clasing et al. 1994, Jaramillo et al. 2007). Most of these species clearly show a suspension feeding behavior (e.g. Mytilus chilensis, Venus antiqua). On the other hand, others

* Invited author

\begin{abstract}
The feeding behavior of two populations of the bivalve Tagelus dombeii (Lamarck, 1818) was studied through laboratory experiments, with the purpose of establishing a possible dual feeding strategy (suspensivore/detritivore). Individuals from both the intertidal population of Coihuín (near Puerto Montt, Chile) as well as those from the subtidal of Corral Bay (near Valdivia) showed continuous suspension feeding with total absence of deposit feeding when immersed, and always showed their open siphons flush with the sediment surface. These observations were confirmed by the high clearance rates shown by both populations of $T$. dombeii, similar to the ones described for obligate suspension feeding bivalves. Different results were obtained during emersion, since $T$. dombeii individuals from both populations displayed their siphons on the sediment (3-5 cm), thus behaving as deposit feeders. Deposit feeding was observed in up to $80 \%$ of individuals. The present study allows to conclude that $T$. dombeii is primarily a suspension-feeder, which might be related to the dominance of sand $(>92 \%)$ in the habitat of both populations studied. Growth coincides with periods of suspended particulate food supply increase in the natural environment. This suggests that $T$. dombeii would be competing for the particulate food supply with the community of obligate suspension feeding bivalves in these habitats.
\end{abstract}

Key words: Bivalve, tidal flat

species such as Tagelus dombeii (Tellinacea) behave as deposit feeders and/or as facultative suspension feeders as can be expected from their siphon morphology (Yonge 1949), thus allowing to expand the period of good food supply in a geographical area where the primary productivity is restricted to a short period of 2-3 months (Navarro et al. 1993). This feeding strategy has been widely described for Macoma balthica (Tellinacea), a common species inhabiting tidal flats of Europe (Hummel 1985, Thompson \& Nichols 1988, Kamermans 1994). 
Suspension feeding bivalves obtain their food (i.e. suspended particulate matter), from the water column, whereas deposit feeders base their feeding on the particulate organic material which is deposited on the sediment. This food material is generated by the benthic primary productivity and by organic particles settling from the water column, which may correspond to phytoplankton, biodeposits (faeces and/or pseudofaeces) and/or detritus (Navarro \& Thompson 1997). It is stated by Levinton (1972) that the deposit and suspension feeding behaviors would produce different degrees of food limitation and therefore competition for it. Thus, at a local scale, food will be more limited for the deposit-feeders than for the suspension-feeders. According to Cadée (1984), Hummel (1985) and 'Olafsson (1986), food absence on the sediment surface or higher food availability suspended in the water column would be factors leading to a change in feeding behavior from deposit feeding to suspension feeding.

The aim of the present study is to asses through laboratory experiments, the feeding behavior of the bivalve Tagelus dombeii (Lamarck, 1818) exposed to different feeding conditions, in order to establish the occurrence of a dual feeding strategy of suspension vs. deposit feeding.

\section{Material and methods}

\section{Experimental conditions}

Laboratory experiments were carried out with Tagelus dombeii specimens of two populations. T. dombeii from

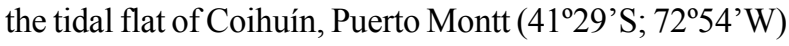
ranged between 6.1 and $7.2 \mathrm{~cm}$ shell length and weighed between 1.1 and $1.7 \mathrm{~g}$ (dry tissue weight), whereas individuals from Corral Bay near Valdivia (39 $52^{\circ}$ 'S; $72^{\circ} 24^{\prime} \mathrm{W}$ ) showed slightly larger sizes, with a shell length between 6.5 and $7.8 \mathrm{~cm}$ and somatic weight between 1.5 and $1.9 \mathrm{~g}$ (dry weight). Individuals collected from both habitats were transported to the laboratory of ecophysiology at the Universidad Austral de Chile, where they were acclimated in aquaria of $10 \mathrm{~L}$ volume for one week at a temperature of $14^{\circ} \mathrm{C}$ and seawater salinity of $30 \mathrm{psu}$. During this period they were fed 'ad libitum' with a mixing diet of the microalga Isochrysis galbana and fine sediment. Each aquaria contained a sediment layer of $25 \mathrm{~cm}$ thick, which had been previously obtained from each sampling site (Coihuín and Corral) and combusted during $16 \mathrm{~h}$ at $500^{\circ} \mathrm{C}$ to eliminate its organic content. The experiments were carried out using 5 animals per aquarium (3 replicates) plus a control aquarium without animals. Clams were fed continuously using a Masterflex 7519-05 peristaltic pump during the time they were maintained in the laboratory and seawater was changed every $48 \mathrm{~h}$.

\section{Sediment analysis}

To analyse the textural and granulometric characteristics of the sediment inhabited by Tagelus dombeii, samples from both sites were taken by means of a sampling probe ( $3 \mathrm{~cm}$ diameter) to a depth of $5 \mathrm{~cm}$ from the intertidal sediment of Coihuín (Puerto Montt) and from the subtidal sediment of Corral Bay (Valdivia).

Textural analysis of sediment was carried out by sifting samples and separating the fractions into gravel $(>2 \mathrm{~mm})$ and sand-aggregates $(>63 \mu \mathrm{m})$ (Anderson et al. 1981). The sand fraction was subsequently sonicated for 30 minutes and sifted through a $63 \mu \mathrm{m}$ mesh to eliminate mud aggregates in sand. Sediment organic content was estimated through drying $\left(80^{\circ} \mathrm{C}, 72 \mathrm{~h}\right)$ and subsequent ashing $\left(500^{\circ} \mathrm{C}, 4 \mathrm{~h}\right)$ (Folk 1980). Mean particle size of sand was estimated by means of settling velocity (Emery 1938) according to the method of moments (SewardThompson \& Hails 1973).

\section{Experimental diets}

In order to simulate the natural suspended particulate matter (seston), a mixed diet was prepared from a mixture of the microalgae Isochrysis galbana and fine sediment collected from the intertidal zone of the Queule Estuary $\left(39^{\circ} 20^{\prime} \mathrm{S} ; 7^{\circ} 13^{\prime} \mathrm{W}\right)$. The resulting particle mixture presented a mean size between 3.5 and $8.4 \mu \mathrm{m}$ and an organic content ranging between 53.1 and $66.2 \%$. A particle concentration fluctuating between 1.2 and $6.3 \mathrm{mg}$ $\mathrm{L}^{-1}$ was offered to the different treatments.

\section{Suspension feeding}

To evaluate the capacity of Tagelus dombeii to feed on suspended particles, twelve consecutive measurements were carried out during a period of two months. For this purpose, five specimens were placed at the bottom of each aquarium $(n=3)$ and allowed to bury completely to a similar position as observed in nature for at least one night before measuring their clearance rate (i.e. volume of water cleared of particles per unit of time, according to Coughlan 1969) in a static system, where the decrease of particle concentration in the experimental aquarium in relation to time was measured within 4 to 6 hours. A mixed diet of the microalgae Isochrysis galbana and fine sediment was offered at a concentration of $50 \times 10^{6}$ particles $\mathrm{L}^{-1}$ homogenised by aeration. Particle concentration was measured every 15 minutes with a particle counter ELZONE $180 \mathrm{XY}$ fitted with a counting tube of $120 \mu \mathrm{m}$ opening, replacing the amount of diet consumed in that period to the initial particle 
concentration. An additional aquarium, with the same characteristics but without animals, was used as control, to evaluate a possible change in particle concentration due to either cellular division or particle sedimentation.

\section{Deposit feeding in immersed animals}

To evaluate whether Tagelus dombeii behaves as a deposit feeder, animals were kept in the experimental aquaria ( $\mathrm{n}$ $=3$ ) during two weeks with permanent food input (mixed diet, Isochrysis galbana + fine sediment: $50 \times 10^{6}$ part $\mathrm{L}^{-1}$ ), and water renewal every other day, resulting in organic enrichment of the sediment surface, either due to sedimentation of microalgae or due to the faecal material produced by this species, partially simulating a natural condition. One day before starting the observations on deposit feeding, the addition of the diet was interrupted, whereas an emulsion prepared with a mixture of particles of organic origin (powder tissue from the clam Venus antiqua) and inorganic fluorescent particles was carefully added on the bottom by means of a syringe, immediately before starting the experiments to produce traceable sediment organic enrichment. The size of this particle mixture (organic + inert) fluctuated between 5 and 30 $\mu \mathrm{m}$ with $75 \%$ of organic matter content. Animal behavior was observed in the three experimental aquaria to prove a possible deposit feeding behavior, described on Tellinacean species as the extension and circular movements of the inhalant siphons on the sediment surface to ingest the food material (Yonge 1949, Pohlo 1969, 1982). Observations were repeatedly carried out (i.e. 1520 times a day) during four consecutive days, repeated on four occasions and registered by means of photography.

\section{Deposit feeding in exposed animals}

Since Tagelus dombeii is only exposed to air during spring-tides at the tidal flat of Coihuín, this condition was simulated in the laboratory with both populations by gradually eliminating all seawater $(10 \mathrm{~L})$ contained in each aquarium to test the occurrence of deposit feeding behavior of exposed T. dombeii. Each aquarium $(\mathrm{n}=3)$ contained 5 individuals on which observations were carried out 15-20 times per day for two consecutive days, and repeated on two occasions. The main observations of these experiments were registered by means of photographs.

\section{Statistical analysis}

Data on clearance rate were verified for normality and homocedasticity through the Kolmogorov-Smirnov test and analysed through the non parametric test of KruskalWallis as not homocedastic (Sokal \& Rohlf 1981). A significance level of 5\% was considered and all analyses were performed with the statistical package SYSTAT v. 5.0.

\section{Results}

\section{Sediment characteristics}

The sediment of both habitats was dominated by the sand fraction, which reached a mean content of $95.6 \%$ and $92.4 \%$ in Coihuín and Corral, respectively (Table 1). The mud component was lower in Coihuín $(0.03 \%)$ than in Corral (7.31\%), with a similar trend observed for organic matter content, which reached $3.12 \%$ in Coihuín and $9.94 \%$ in Corral (Table 1).

Table 1

Textural characteristics of sediments (total sediment and sand fraction) from the tidal flat of Coihuín and subtidal of Corral, $(X \pm$ s.e. $=$ Average \pm standard error $)$

Características texturales del sedimento (total y fraccion de arena) de la planicie mareal de Coihuín y submareal de Corral $(\mathrm{X} \pm$ e.e. $=$ Promedio \pm error estándar $)$

\begin{tabular}{|c|c|c|c|c|c|c|c|c|c|c|c|}
\hline & \multirow[b]{2}{*}{ SAMPLE } & \multicolumn{5}{|c|}{ COIHUÍN } & \multicolumn{5}{|c|}{ CORRAL } \\
\hline & & 1 & 2 & 3 & 4 & $X \pm$ s.e & 1 & 2 & 3 & 4 & $X \pm$ s.e \\
\hline \multirow{5}{*}{ 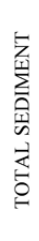 } & $\%$ Gravel & 0.97 & 4.78 & 3.55 & 7.08 & $4.1 \pm 1.27$ & 0.12 & 0.01 & 0.09 & 0.092 & $0.08 \pm 0.0$ \\
\hline & $\%$ Sand & 98.67 & 95.05 & 96.07 & 92.69 & $95.6 \pm 1.24$ & 91.38 & 92.51 & 93.93 & 91.8 & $92.4 \pm 0.5$ \\
\hline & $\%$ Mud & 0.04 & 0.023 & 0.037 & 0.037 & $0.03 \pm 0.003$ & 8.36 & 7.29 & 5.66 & 7.93 & $7.31 \pm 0.5$ \\
\hline & $\%$ Biogenic Aggregate & 0.32 & 0.14 & 0.29 & 0.19 & $0.24 \pm 0.04$ & 0.14 & 0.18 & 0.32 & 0.18 & $0.21 \pm 0.0$ \\
\hline & $\%$ Organic Matter & 6.31 & 2.82 & 2.62 & 0.72 & $3.12 \pm 1.16$ & 8.86 & 11.09 & 9.58 & 10.22 & $9.94 \pm 0.4^{\prime}$ \\
\hline \multirow{4}{*}{ 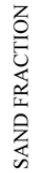 } & Mean grain size $\varnothing(\mathrm{x})$ & 1,00 & 0.55 & 0.78 & 0.52 & $0.71 \pm 0.11$ & 2.18 & 2.22 & 2.05 & 2.11 & $2.14 \pm 0.0$ \\
\hline & Sorting (S.D) & 0.93 & 0.7 & 0.77 & 0.74 & $0.79 \pm 0.10$ & 0.85 & 0.86 & 0.79 & 0.88 & $0.85 \pm 0.0$ \\
\hline & Skewness (Sk) & 3.79 & 0.47 & 0.13 & 0.99 & $1.35 \pm 0.83$ & -0.49 & -0.45 & -0.07 & -0.32 & $-0.33 \pm 0.0$ \\
\hline & Kurtosis (K) & 31.98 & 2.97 & 2.48 & 3.7 & $10.28 \pm 7.24$ & 2.31 & 2.28 & 2.11 & 2.3 & $2.25 \pm 0.0$ \\
\hline
\end{tabular}


Mean size and sorting of sand particles $(0.71$ and 0.79 phi, respectively) of Coihuín sediment allows sediment classification as 'thick sands moderately selected' (Folk 1980), whereas the same parameters for Corral sediments were 2.14 and $0.85 \mathrm{phi}$, respectively, thus classified as 'fine sands moderately selected' (Folk 1980).

\section{Suspension feeding}

Tagelus dombeii individuals from Coihuín, the tidal flat (thick sands), behave as suspension-feeders. Feeding activity, measured as clearance rate $\left(\mathrm{L} \mathrm{h}^{-1}\right)$, showed a continuous suspension feeding behavior that ranged between 1.1 and $2.8 \mathrm{~L} \mathrm{~h}^{-1}$ (Fig. 1), with a mean rate ( \pm $\mathrm{SE})$ of $2.1 \pm 0.18 \mathrm{~L} \mathrm{~h}^{-1}(\mathrm{n}=12)$. Clearance rate was very similar between the experimental aquaria, and showed clams with their siphons widely open and flush with the sediment surface (Fig. 2a). Due to this high filtration activity, high faeces production was observed being deposited on the sediment surface where the animals were buried. T. dombeii did not present pseudofaeces production (i.e. filtered material eliminated before being ingested) in the range of particle concentration used in the experiments $\left(1.2-6.3 \mathrm{mg} \mathrm{L}^{-1}\right)$.

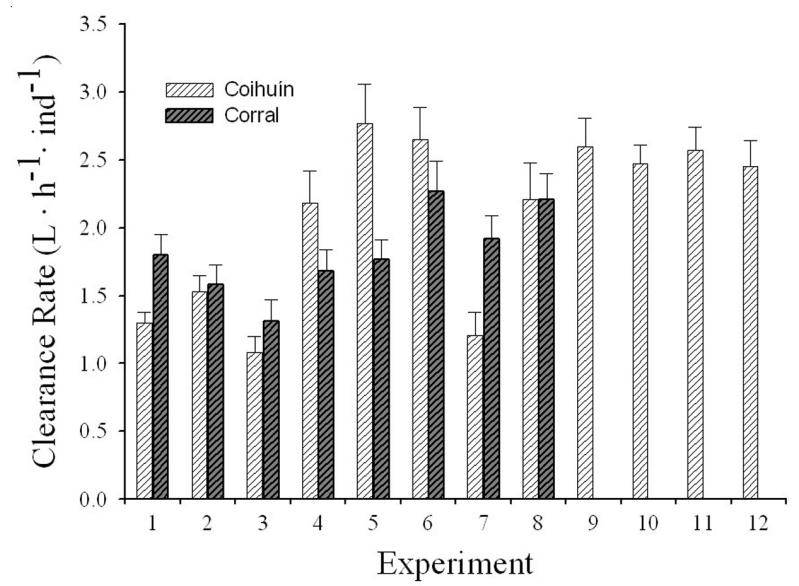

Figure 1

Tagelus dombeii. Clearance rate of individuals from the tidal flat of Coihuín and from the subtidal of Bahía Corral. Values are means \pm standard error

Tagelus dombeii. Tasa de aclaramiento de individuos de la planicie mareal de Coihuín y del submareal de la bahía de Corral. Valores corresponden a promedios \pm error estándar
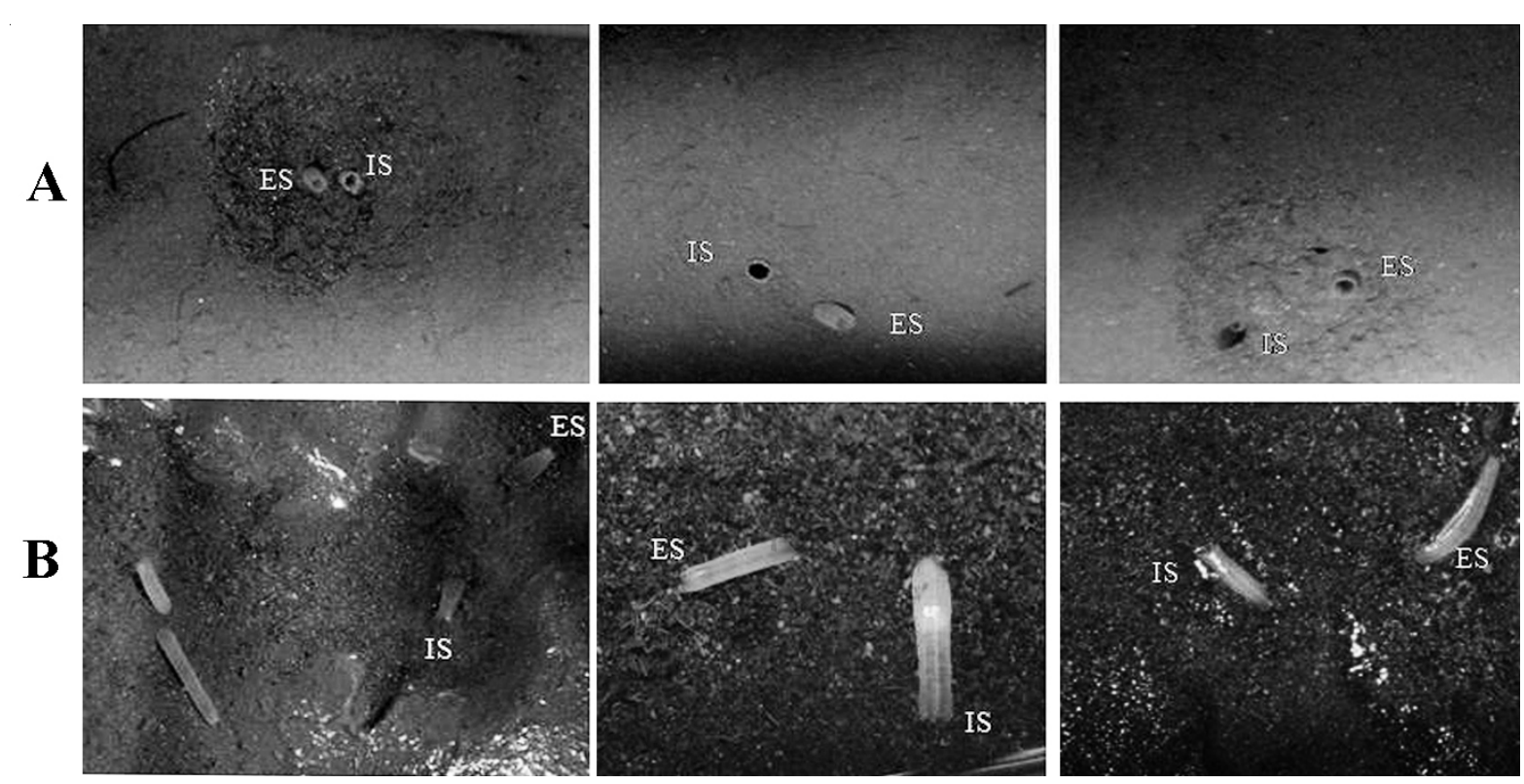

Figure 2

Tagelus dombeii. Photographs of (A) immersed and (B) exposed individuals buried in the sediment of the aquaria. Inhalant siphons (IS); Exhalant siphons (ES)

Tagelus dombeii. Fotografías de individuos (A) sumergidos y (B) expuestos, enterrados en el sedimento de los acuarios. Sifones inhalantes (IS); sifones exhalantes (ES) 
Similar results were obtained with the samples from Corral (fine sand), where T. dombeii also behaved as an active suspension-feeder, with clearance rate ranging between 1.3 and $2.3 \mathrm{~L} \mathrm{~h}^{-1}$ (Fig. 1) and mean rates ( $\pm \mathrm{SE}$ ) of $1.82 \pm 0.11 \mathrm{~L} \mathrm{~h}^{-1}(\mathrm{n}=8)$.

Comparison of clearance rates between both $T$. dombeii populations showed no significant differences between them (K-W: $\mathrm{H}(1, \mathrm{n}=20)=1.09 P=0.30)$. Not a single individual was observed with their siphons extended during the experiments, a fact of behavioral consistency that suggests a non deposit feeding strategy under these experimental conditions.

\section{Deposit feeding in immersed animals}

Tagelus dombeii from neither populations responded as deposit feeders faced to experimental conditions during immersion. All individuals behaved in the same way, with the inhalant siphons completely buried and its opening flush with sediment surface (Fig. 2a), similar to the behavior observed during the suspension feeding experiments. Considering that both inhalant siphons position and the occurrence of a very limited suspended food supply, it can be concluded that the immersed animals of both studied populations are not directly using the food supply deposited on the sediment surface. These observations are in agreement with the fact that there was no apparent reduction of particulate food material deposited on the sediment surface.

\section{Deposit feeding in exposed animals}

Tagelus dombeii individuals exposed to air showed a deposit feeding behavior by displaying their siphons (3$5 \mathrm{~cm}$ ) into the water/sediment interface created in the aquaria as water was drained, simulating conditions during low tide (Fig. 2b). As a result these animals started to pull in the fine material from the surface, leaving marks on the sediment and showing active movements of water currents inside the siphons. This behavior was observed in up to $80 \%$ of individuals from both the intertidal flat of Coihuín and the subtidal area of Corral. Thus, the capacity of this species to behave as a deposit-feeder is demonstrated under conditions of air exposure and just a small film of water over the sediment surface.

\section{Discussion}

The results of the present study indicate that Tagelus dombeii from both habitats presenting a range of thick sandy sediments (intertidal flat of Coihuín), and fine sandy sediments (subtidal, Bahía Corral) behave as suspensionfeeders when immersed. This behavior is characterised by locating siphons flush with the sediment surface in addition to high feeding activity. The large fluctuation of the clearance rate $\left(1.1\right.$ to $\left.2.8 \mathrm{~L} \mathrm{~h}^{-1}\right)$ was partly due to the wide range of body weight of the experimental animal. However this rates are within the range described for obligated suspension feeding species of similar size, e.g. Mytilus edulis (Bayne \& Widdows 1978, Thompson 1984), Mytilus galloprovincialis (Navarro et al. 1991), Cerastoderma edule (Navarro \& Widdows 1997). These results are in agreement with the observations carried out through autonomous diving throughout the year above natural population of $T$. dombeii at Coihuín, where individuals kept their siphons open at level with the sediment surface as observed also in experimental aquaria. Results obtained from laboratory experiments are not related to the lack of food on the bottom, because a significant amount of organic detritus was added to the sediment. However, the short time of exposure (four days) to conditions of lower food concentration in water coupled to higher sediment concentration could be insufficient for the animal to change its behavior. The lack of deposit feeding behavior in submerged $T$. dombeii, can also be related with the adaptation to avoid predation by the gastropod Nassarius gayi that is abundant in its habitat, or by other organisms as fishes and crustaceans as it was described by Vlas (1985) and Zwart \& Wanink (1989) for other species of benthic bivalves. However, this behavioral pattern can also be related with the kind of the sediment found in the habitat of both populations, which is mainly composed by sand (>92\%) and with very little mud (0.03-7.3\%). In relation with this statement, 'Olafsson (1986) found that Macoma balthica from sandy sediments behaves mainly as suspension-feeder whereas its populations from muddy sediments presented deposit feeding behavior. Our results are in agreement with $T$. dombeii growth data, because the main weight increase in the different tissues (i.e. soma, gonad and digestive gland) are related to the increase in suspended food supply (seston), quantified as either chlorophyll $a$, centric diatoms or microflagellate biomass (Urrutia et al.2001), and coincides with descriptions for other species belonging to the tellinid group (Hummel 1985, Kamermans 1994, Kamermans et al. 1992). Considering the morphological characteristics of $T$. dombeii siphons (i.e. very long and protractile) in addition to tellinid functional morphology (Yonge 1949), it could be expected that this species behaves as deposit feeder when living in habitats with finer sediment and rich in organic matter; a fact that would allow for a higher capacity to process the smallest particles at the level of the gills and mouth palps. To prove this hypothesis experiments must be carried out with animals coming from a population living in a habitat with sediment considerably finer than those examined in the present study. Thus is the case for Macoma balthica, 
a species considered a typical deposit-feeder which is found inhabiting sediments with high fine particle content. Hummel (1985) found in a population of M. balthica from the north of Europe (Dutch Wadden Sea) that this species behaves $55.2 \%$ of its feeding time as deposit-feeder throughout most of the tidal cycle of the months outside of its main growth period. However, this author concludes that although M. balthica predominates as a depositfeeder, it primarily food source is found in the water column. Similar results have been described by Kamermans (1994) when comparing the feeding behavior of facultative deposit feeding organisms with other obligated suspension-feeders, because both groups seem to use the same feeding source, and observed a high correlation between microalgal composition inside the bivalve stomach and that present in the water column, but a low correlation with sediment microalgal composition. A possible explanation for these results is that species as M. balthica and Scrobicularia plana would have the capacity to inhale large volumes of water while collecting material from the sediment surface (Hughes 1969, Yonge \& Thompson 1976, Hummel 1985). Different results were observed on individuals of $T$. dombeii during emersion; after some minutes animals displayed their siphons over the sediment/water interface and began to behave as deposit-feeders. Direct observations at the tidal flat of Coihuín during spring low tide allowed, in rare opportunities, to observe individuals showing the same behavior. As time of exposure to air occurs only for a few hours during spring low tides at Coihuin tidal flat, it is expected that the amount of food obtained through this behavior would not be significant when compared to the food acquired under a suspension feeding mode. Furthermore, Lardies et al. (2001) described the annual pattern of burial depth in natural populations of the bivalves T. dombeii and Venus antiqua (obligated suspension feeder) in relation to annual food availability in both the water column and sediment, at Coihuín tidal flat. The burial depths dynamics for both species showed a strong correlation with food availability in water column, approximately $60 \%$ of the variability in burial depth in both species was explained by concentration of chlorophyll a in the water column (Lardies et al. 2001). That is, food concentration on the sediment did not affect the burial depth of $T$. dombeii supporting the pattern obtained in laboratory, indicating that deposit feeding seems to have a minor significance in $T$. dombeii. The low number of individuals displaying this behavior in the natural habitat can be explained as a strategy of avoidance of predators, such as the large quantity of birds and gastropods predating over the intertidal zone of the tidal flats from southern Chile. The deposit feeding activity in $M$. balthica during emersion was also observed by Hummel (1985). Similarly he did not consider this strategy as significant towards total food ingested, because emersion only occurred during short periods that range between 3.4 and $12.2 \%$ of its total time of air exposure, and thus contributed towards ca. $5 \%$ of total food ingested. Thus, it can be concluded that Tagelus dombeii, would be competing for suspended particulate matter (seston) with co-existing obligate suspension feeding bivalves, such as Mytilus chilensis and Venus antiqua, by using the same energy provided by primary productivity events.

\section{Acknowledgments}

The authors thank to Geysi Urrutia and Maritza Araneda for the permanent help in the laboratory experiments. This research was supported by the Fondo Nacional de Investigación Científica y Tecnológica (Fondecyt-Chile Grant $N^{\circ} 1951202$ ) and partially by the Canadian International Development Agency Tier II award to Memorial University of Newfoundland and the Universidad Austral de Chile. Finally, the authors thank the anonymous reviewers for improving this manuscript.

\section{Literature cited}

Anderson FE, L Black, LM Mayer \& LE Watling. 1981. A temporal and spatial study of mudflat texture. Northeastern Geology 3: 184-191.

Bayne BL \& J Widdows. 1978. The physiological ecology of two populations of Mytilus edulis L. Oecología 37: 137162.

Cadée GC. 1984. 'Opportunistic feeding', a serious pitfall in trophic structure analysis of (paleo) faunas. Lethaia 17:289292.

Clasing E, T Brey, R Stead, JM Navarro \& GAsencio. 1994. Population dynamics of Venus antiqua (Bivalvia: Veneracea) in the bahía de Yaldad, Isla de Chiloé, Southern Chile. Journal of Experimental Marine Biology and Ecology 177: 171-186.

Coughlan J. 1969. The estimation of filtering rate from the clearance of suspensions. Marine Biology 2: 356-358.

Emery KO. 1938. Rapid method of mechanical analysis of sands. Journal of Sedimentary Petrology 8: 105-111.

Folk R. 1980. Petrology of sedimentary rocks. Hemphill Pub. Co., Texas, $182 \mathrm{pp}$.

Hughes RN. 1969. A study of feeding in Scrobicularia plana. Journal of the Marine Biological Association of the United Kingdom 49: 805-823.

Hummel H. 1985. Food intake of Macoma balthica (Mollusca) in relation to seasonal changes in its potential food on a tidal flat in the Dutch Wadden Sea. Netherlands Journal of Sea Research 19: 52-76.

Jaramillo E, H Contreras \& C Duarte. 2007. Community structure of the macroinfauna inhabiting tidal flats 
characterized by the presence of different species of burrowing bivalves in Southern Chile. Hydrobiology 580: 85-96.

Kamermans P. 1994. Similarity in food source and timing of feeding in deposit - and suspension-feeding bivalves. Marine Ecology Progress Series 104: 63-75.

Kamermans P, HW Van der Veer, L Karezmarski \& GW Douglas. 1992. Competition in deposit - and suspensionfeeding bivalves: experiments in controlled outdoor environments. Journal of Experimental Marine Biology and Ecology 162: 113-135.

Lardies MA, E Clasing, JM Navarro \& RA Stead. 2001. Effects of environmental variables on burial depth of two infaunal bivalves inhabiting a tidal flat in southern Chile. Journal of the Marine Biological Association of United Kingdom 81: 809-816.

Levinton J. 1972. Stability and trophic structure in depositfeeding and suspension-feeding communities. American Naturalist 106: 472-486.

Navarro E, JIP Iglesias, A Pérez-Camacho, U Labarta \& R Beiras. 1991. The physiological energetics of mussels (Mytilus galloprovincialis Lmk) from different cultivation rafts in the Ría de Arosa (Galicia, N.W. Spain). Aquaculture 94: 197-212.

Navarro JM, E Clasing, G Urrutia, GAsencio, R Stead \& C Herrera. 1993. Biochemical composition and nutritive value of suspended particulate matter over a tidal flat of southern Chile. Estuarine, Coastal and Shelf Science 37: 59-73.

Navarro JM \& RJ Thompson. 1997. Biodeposition by the horse mussel Modiolus modiolus (Dillwyn) during the spring diatom bloom. Journal of Experimental Marine Biology and Ecology 209: 1-13.

Navarro JM \& J Widdows. 1997. Feeding physiology of Cerastoderma edule (L.) in response to a wide range of seston concentrations. Marine Ecology Progress Series 152: 175-186.

'Olafsson EB. 1986. Density dependence in suspensionfeeding and deposit-feeding populations of the bivalve
Macoma balthica: a field experiment. Journal Animal Ecology 55: 517-526.

Pohlo RH. 1969. Confusion concerning deposit feeding in the Tellinacea. Proceedings of the Malacological Society of London 38: 361-364.

Pohlo RH. 1982. Evolution of the Tellinacea. Journal of Molluscan Studies 48: 245-256.

Seward-Thompson B \& J Hails. 1973. An appraisal of the computation of statistical parameters in grain size analysis. Sedimentology 11: 161-169.

Sokal RR \& FJ Rohlf. 1981. Biometry, 859 pp. W.H. Freeman and Co., San Francisco.

Thompson RJ. 1984. The reproductive cycle and physiological ecology of the mussel Mytilus edulis in a subarctic, nonestuarine environment. Marine Biology 79: 277-288.

Thompson JK \& FH Nichols. 1988. Food availability controls seasonal cycle of growth in Macoma balthica (L.) in San Francisco Bay, California. Journal of Experimental Marine Biology and Ecology 116: 43-61.

Urrutia GX, JM Navarro, E Clasing \& RA Stead. 2001. The effects of environmental factors on the biochemical composition of the bivalve Tagelus dombeii (Lamarck, 1818) (Tellinacea: Solecurtidae) from the intertidal flat of Coihuín, Puerto Montt, Chile. Journal of Shellfish Research 20: 1077-1088.

Vlas J. 1985. Secondary production by siphon regeneration in a tidal flat population of Macoma balthica. Netherlands Journal of Sea Research 19: 147-164.

Yonge CM. 1949. On the structure and adaptations of the Tellinacea, deposit-feeding Eulamellibranchia. Philosophical Transactions of the Royal Society (Ser. B.) 234: 29-76.

Yonge CM \& TE Thompson. 1976. Living marine molluscs. 288 pp. Collins, London.

Zwarts L \& J Wanink. 1989. Siphon size and burying depth in deposit - and suspension - feeding benthic bivalves. Marine Biology 100: 227-240. 